\title{
Masculinity and the Wounds of the First World War: A Centenary Reflection
}

Un siècle après, retour sur la masculinité et les blessures de la Première Guerre mondiale

\section{Ana Carden-Coyne}

\section{CpenEdition}

\section{Journals}

Electronic version

URL: http://journals.openedition.org/rfcb/305

DOI: $10.4000 / \mathrm{rfcb} .305$

ISSN: 2429-4373

\section{Publisher}

CRECIB - Centre de recherche et d'études en civilisation britannique

Printed version

Date of publication: 15 January 2015

ISSN: 0248-9015

\section{Electronic reference}

Ana Carden-Coyne, « Masculinity and the Wounds of the First World War: A Centenary Reflection », Revue Française de Civilisation Britannique [Online], XX-1 | 2015, Online since 01 May 2015, connection on 10 December 2020. URL : http://journals.openedition.org/rfcb/305 ; DOI : https://doi.org/10.4000/ rfcb.305

This text was automatically generated on 10 December 2020 .

\section{(c) $(1)$}

Revue française de civilisation britannique est mis à disposition selon les termes de la licence Creative Commons Attribution - Pas d'Utilisation Commerciale - Pas de Modification 4.0 International. 


\title{
Masculinity and the Wounds of the First World War: A Centenary Reflection
}

\author{
Un siècle après, retour sur la masculinité et les blessures de la Première Guerre \\ mondiale
}

Ana Carden-Coyne

1 In the year of the centenary of the First World War, it is timely to reflect upon the rise of masculinity studies and its impact on the historiography of Britain's military culture and the changing landscape of focused studies of the war. To be sure, many historians now regard gender and war as 'inevitably intertwined', as Alison Fell recently argued. ${ }^{1}$ In this essay, I will examine the historiography of the First World War, as it relates to the study of military masculinities, the rising scholarship on wounded, disabled and colonised bodies, and then reflect on my own response to the centenary.

2 Two other worthy anniversaries coincide with 2014. It is twenty years since the publication of two ground-breaking and now seminal academic texts: Joanna Bourke's Dismembering the Male: Britain, Male Bodies and the Great War (Reaktion, 1994) and Graham Dawson's Soldier Heroes: British Adventure, Empire and the Imagining of Masculinities (Routledge, 1994). Together, they demonstrated how masculinity underpinned imperialism and militarism, fundamentally shaping the experience of modern war as social, embodied and psychological experiences. Few social or cultural histories are published today without due debt to such classic works and, as this essay will explain, historians are habitually 'intertwining' gender through their studies of culture, disability, race and sexuality during the First World War.

3 Though, arguably, gender history is still often equated with the study of women (and implicitly femininity), masculinity has been named as an explicit subject of historical investigation in relation to wartime and militarism. Following on from Dawson's concept of the 'soldier hero', Michael Paris' Warrior Nation (2001), made explicit the relationship between military masculinity and national identity through the image of the chivalrous 
warrior pervasive in British popular fiction and consumer culture. Dawson's notion of 'the pleasure culture of war' was also advanced in Bourke's important critique of the 'warrior myth'. In An Intimate History of Killing: Face-to-Face Killing in Twentieth Century Warfare (Granta, 1999), popular films and fiction shaped masculine bravado and violent conduct in the two world wars.

4 To be sure, Graham Dawson's psycho-historical tenet, and his capacity to link the structure of memory to that of gender in popular images of the soldier hero, fostered willingness among some historians to go beyond social constructions of masculinity and engage with the history of the emotions. Recently, pioneer historian of masculinity, Michael Roper, used Kleinian psychoanalysis to shape his analysis of 'emotional survival' among soldiers who wrote to their mothers during the First World War (The Secret Battle: Emotional Survival in the Great War, 2012). ${ }^{2}$ That Roper published this important book in a 'cultural history of modern war series' is telling of the trajectory of influences in historiography. Indeed, the development of the cultural history of war has reframed investigations into war, militarism, mobilisation, and soldiers' bodies and minds, as cultural phenomena and situated them in the context of the production, reception and aesthetics of many diverse forms of representation. ${ }^{3}$

\section{Disobedient Military Masculinities}

5 A common starting point for historians has been that the First World War was a modern, technological war that tested and broke Victorian and Edwardian codes and expectations of manliness. Thus studies of military medicine in the treatment of shellshock had to contend with the Victorian education of most military psychiatrists, who reached for the tools of class and gender to explain the seemingly inexplicable - men falling apart. Masculinity thus gained ground in scholars' interpretations of how psychiatric medicine diagnosed and treated the condition. Shellshock as a result of modern war was situated within both class and gender frameworks, as a 'crisis' of masculinity.

Drawing from Eric Leed's 1979 argument that the slaughter of mechanised warfare annihilated belief in heroism, and that hysteria was a protest against the inhumanity of industrial warfare, Elaine Showalter placed gender firmly at the heart of the issue. Drawing from her research on hysterical women, her compelling arguments made in 1987 and 1997 framed shellshock as a 'body language of masculine complaint'. The expectations of stoicism and heroism placed on individuals were no match for the scale and reach of industrialised slaughter. ${ }^{4}$ Mark Micale subsequently expressed dissatisfaction with the 'crisis' thesis. Laurinda Stryker also wanted more precise evidence to map the causes of male breakdown, 'sexual impotence', and gender anxiety, noting the military psychologists were neither obsessed with gender nor cowardice. Similarly challenging the 'crisis' thesis, Tracy Loughran argued for a more nuanced approach to the medical and social history of both the diagnosis and experience of psychological wounds. ${ }^{5}$

7 However, some recent interventions have shown that masculinity in wartime is not simply about the pervasive military ideal in British society. Indeed Meyer's book Men of War (2009) showed both that domestic ideals of masculine endurance and restraint existed alongside military identities shaped around heroism and sacrifice. ${ }^{6}$ Focusing on the period of the war and extending to its long aftermath, Gabriel Koureas identified an ideal of 'unconquerable manhood' in British visual culture. Koureas argued that the 
political construction of memorials rendered the memory of the war in terms of heroic sacrifice, which not only avoided the issue of trauma and disability, but reflected wider anxieties about working-class masculinity, particularly in the light of post-war civil discontent.7 In editing Gender and War Since 1914: Historical and Interdisciplinary Perspectives (Palgrave, 2013), I encouraged cross-disciplinary dialogue between scholars working in masculinity studies, in conversation with feminist scholars Cynthia Enloe and Judith Butler, to articulate different ways in which gender fundamentally shapes war and vice versa, with essays on internment (Matthew Stibbe), civil defence (Susan Grayzel and Lucy Noakes), physical and emotional wounding (Hazel Croft; Jessica Meyer), and male pacifism (Lois Bibbings). Military masculinity may be resilient but it encounters a significant degree of both disobedience and outright opposition.

Indeed, one of the most under-acknowledged aspects of military masculinity in the First World War has been that of conscientious objection. Lois Bibbings has investigated the treatment of COs, Quakers and other pacifists. In Telling Tales about Men (2010), and several other studies, Bibbings has shown that pacifist men were continually subjected to cruel treatment (despite their legal capacity to object) and much of their punishment and character assassination was gender-based - there was nothing more effeminate and cowardly than a man willing to stand up for his beliefs when the nation was mobilised behind the war effort and behind the very essentialised construct of the citizen soldier's masculinity. ${ }^{8}$

9 Alongside disobedient masculinities in the history of WW1, are gender categories that seem to refuse comfortable conceptualisation, and this is especially pertinent when viewed through the lens of sexuality. Though historians of the First World War have examined gender (femininity) and masculinity, with a few looking at this in relationship, the impact of war on sexuality and sexual behaviour has been more troublesome. Sexuality seem to be in an enclave rather than taken as a fundamental category of analysis. Laura Doan, however, fully integrated 'queer critical theory' into her analysis of how 'heterosex' operated in military education regarding venereal disease, for instance, and in what should become a classic intervention, her recent monograph Disturbing Practices: History, Sexuality and Women's Experience of Modern War (Chicago University Press, 2013). ${ }^{9}$ The book offers a substantial critique of the inappropriate use of sexual identities in discussions about women and sex in WW1, while also providing a historically sensitive account of the fluid 'topsy-turvy' character of gender constructs in the period. Using the example of female ambulance drivers and the formidable nursing team of Elsie Knocker and Mairi Chisolm, Doan aims to 'disturb' the assumptions about, and conflations of, gender and sexuality, based on a genealogical project; the need to retrieve gay ancestors. Doan provides the most fascinating account of the relationship between the women, and in a second case study provides the most fascinating study of the intriguing smear campaign against Violet Douglas-Pennant the head of the Women's Royal Air Force (WRAF). This should become textbook reading for historians of women, gender, masculinity, but I fear it will be relegated to the enclave study of sexuality.

In my own book, Reconstructing the Body: Classicism, Modernism and the First World War (2009), a similar problem about gender and sexuality was seen in the sexualisation of men in the post-war period. Some readers wanted to project gay culture onto the past bodybuilding industry. Bulging biceps of men walking straight out military units and barracks into gymnasia seeking homosocial comfort and competition looked gay enough, but I tried to warn against interpreting them with presentist eyes. But, what Matt Houlbrook 
did with Dawson's 'solder heroes' thesis was appealingly radical. Houlbrook wove this enduring form of idealised masculinity into the long history of soldier sexuality, focusing on the Guardsman as an emblem of British national identity and militarised masculinity, but crucially, also as an object of queer desire. ${ }^{10}$

By contrast, studies of cross-dressing and female impersonation in the front-line have tended to associate these performances with proto-gay culture or an outlet for repressed homosexuality. ${ }^{11}$ Though new research on male and female impersonation as part of vaudevilliean theatre inside military hospitals, practiced by nurses, doctors and some patients, follows Doan's 'disturbing' approach, adding that men's pain and suffering created intense and fraught intimacies within war hospital communities in which soldiers' bodies were also disciplinary subjects. ${ }^{12}$

\section{Wounded, Disabled and Colonised Bodies}

12 Over the last decade, there has been increasing attention to bodies, disability and rehabilitation. Deborah Cohen's comparative study of veterans in Britain and Germany The War Come Home (2001) explored the failed reconstruction of disabled veterans, and its political consequences, while Jeffrey Reznick's Healing the Nation (2004) examined the rehabilitation process in detail and the social expectations placed on disabled soldiers' bodies. ${ }^{13}$ In 2007, Westminster University's Group for War and Culture Studies launched the Journal of War and Culture Studies. In 2008, a special issue on The Body at War: Wounds, Wounding and the Wounded explored masculinity in the fetishising of bayonet practice and combat (Paul Hodges), in medical ideas about wounding as passive and effeminate and mirrored in military patients self-representations (Ana Carden-Coyne), and in gendered concepts of death and resurrection among the representation of dead soldiers in France (Martin Hurcombe). In addition, a generation of historical studies of military masculinity have been explicitly or implicitly informed by the sociologist R.W. Connell's concept of 'hegemonic masculinity', which has underpinned the way scholars have troubled the gendered concept of the wounded and disabled body. ${ }^{14}$

the history of medicine and war though they appear in implicit ways, such as in Leo van Bergen's Before my Helpless Sight: Suffering, Dying and Military Medicine on the Western Front 1914-1918 (Ashgate, 2009). Comparing British, German and Dutch encounters between bodies and medical systems, the soldier is framed as hero, victim and perpetrator. A recent volume edited by the Senior Curator at the Imperial War Museum, Paul Cornish, and archaeologist Nicholas Saunders, provides a cross-disciplinary conversation about the body in war in terms of its corporeal experience and material affects, shaped by class, race and gender constructs, but also the body as a political tool and object of continual transformation under the conditions of war..$^{15}$ These works reveal in different ways how war wounds, as the experience of frontline casualties and military hospitals, demonstrated the complexity of gender constructs and gendered behaviour in response to the military demands placed on male bodies in wartime and the ambiguous and often anxious social significance of the wounded and disabled.

14 Studies of social experiences and medical representations of wounds expose the entwined failure of reconstruction and masculinity. Carol Acton has also argued that the wounded male body 'paradoxically reinforces gendered binaries' and intersects men and women's war experiences. ${ }^{16}$ Art historians have provided new critical insights into the 
representation of bodies in war art, medical illustrations and memorials, using their specific disciplinary tools. Historians may write about cultural representation and its social contexts, but they are not always sufficiently familiar with the techniques of visual and formal practice in art and architecture. Suzannah Biernoff's work on Henry Tonks' medical illustrations and (with Jane Tynan) Horace Nichols' photographs of the facially wounded is expert. Biernoff argues that extreme suffering and the violation to the face, the touchstone of humanity, undercut fantasies about heroic warfare and the capacity of military masculinity to withstand modern technological warfare. ${ }^{17}$ We eagerly await her forthcoming book, in which she argues that the military body is more than flesh and blood: it is a symbolic site invested with political as well as personal meaning. Valour, heroism, patriotism, courage: these concepts assume visible form, and do their cultural work, when they are personified and embodied' (Portraits of Violence: War and the Aesthetics of Disfigurement, (University of Michigan Press, 2015).

Finally, the most important and yet strangely neglected study of the First World War as a global war has addressed the study of masculinity with that of race and colonised bodies. Richard Smith led the way with an important book Jamaican Volunteers in the First World War (2004), and more recently and essay on 'The Black Male Body in the White Imagination During the First World War'. ${ }^{18}$ The centenary should be an opportunity to raise awareness that there was indeed a British Empire and the First World War drew extensively on its imperial soldiers with social, political and personal consequences that lasted generations. The work of Santanu Das is following suit, with a monograph that engages as much with gender studies as with Empire (India, Empire and the First World War: Words, Images and Music, Cambridge, 2015), while also leading a Europe-wide project on the cultural encounters of the war as they were informed by the intersection of class, race and gender. The colonial gaze and colonial power relations are ripe for the interrogation that masculinity studies should provide.

\section{Commemoration Fever}

The WW1 centenary has barely begun in Britain, and yet we have quickly slipped from a state of commemoration fever to commemoration burnout. However, there are four years ahead of us and there will be more specific centenary events to come, such as the Somme, Lusitania and chemical war (2015); the introduction of conscription (2016) and the role of pacifism and resistance to militarism. Various battles will be commemorated, and 2018 will be a year of thinking about aftermaths, legacies and the meaning and implications of the Armistice and the Treaty of Versailles in the way it shaped the wars and politics of the subsequent century.

Encouragingly, what I wanted to see in the field of research is already happening among some scholars and among out $\mathrm{PhD}$ students, and that is a more comprehensive account of empire and imperial soldiers and their experiences. Though these voices have yet to really make dent in the public understanding of WW1, there is a greater willingness to tackle these issues. More people are also beginning to consider soldiers as fathers and as part of families, and their relationships with women while both combatants and as returned veterans, and to consider the long legacies of the war in the lives of their children, as Michael Roper's new project is revealing.

To turn to my own response to the centenary, I have long been working on bringing together the fields of war surgery with masculinity studies, the history of sexuality, and 
an increasing interest in the sensory and emotional complexity of being wounded and treated within a social environment. In The Politics of Wounds: Military Patients and Medical Power in the First World War (Oxford University Press, 2014), gender is fundamental to social relationships formed during medical evacuation, in surgical treatment and in the practice of nursing care. The focus on military patient's experiences from across the British Empire also suggests further layers of complexity - ethnicity, race, colonialism mixed with the experience of pain, the military pressure to be stoic and return to the front, the shared social pressure that men should reclaim their masculine dignity in overcoming their wounds and disabilities. I argued in this book, that war wounds provoked strong political, social, emotional -even sexual - responses. For some the wound was an opportunity - to reclaim masculinity, to appeal to women's nurturing and romantic ideals, to wear their scars as markers of their duty and honour. For others, the wound represented a huge loss of identity, employability and social status.

The centenary of the First World War certainly has provoked a huge political and public response in the United Kingdom, and much of the funding for local projects have been underpinned by a rather insular political culture. The First World War is almost exclusively British war, and very much a white man's war. Women have been included, but the obsession with trenches (and European ones) reduces the public image of the war to one of white British front-line soldiers. Scholars, however, have been trying very hard to make interventions; dedicated conferences testify to the willingness to interrogate together the global and racial encounter of war, and the gendered experience and legacy of the war. What the BBC does with that, however, is to tell people the familiar stories they want to hear.

Thus over the next four years, with the narrow focus on the British experience of WW1, isolating it from the global contact, academic historians have got their own battle to win - mediatised WW1 versus ivory towers. We continue to try. One way in which I have tried to make an intervention is by working with the city of Manchester's main art gallery on a major art exhibition. An important collection of WW1 collection was formed by the wartime Director, Laurence Hayward, who knew many of the British official war artists and was able to acquire work directly from their studio. Our exhibition, The Sensory War, 1914-2014 (Oct 10, 2014-Jan 2015) explores how artists over the last century have interpreted and communicated the impact of war on the human sensory experience, on the body and mind, and on the environment. Drawing on some of the multi-disciplinary research on sensory perception, war is conceptualised as a 'synaesthetic' experience, highlighting how artists found ways to communicate the sounds of bombs and high artillery explosions, or the sensations of flights in new aerial warfare, the trauma of bombing and burning, and the rupture of disability, alongside the ghostly feelings of sensing the disturbed world of the dead. 


\section{NOTES}

1. Alison Fell, 'Gendering the War Story', JWCS, 1, 1, August, 2007, 53-58. See also John Horne, 'Masculinity in Politics and War in the Age of Nation-States and World Wars, 1850-1950." In Stefan Dudink, Karen Hagemann, and John Tosh eds, Masculinities in Politics and War: Gendering Modern History, Manchester University Press, New York : New York, date, 22-40.

2. Michael Roper, 'Re-Remembering the Soldier Hero: the Psychic and Social Construction of Memory in Personal Narratives of the Great War', History Workshop Journal, 50, 2000, 181-204; ' Between Manliness and Masculinity: the War Generation and the Psychology of Fear in Britain', Journal of British Studies, 44 (2005).

3. See Manchester University Press, Cultural History of Modern War series.

4. Eric Leed, No Man's Land: Combat and Identity in World War 1, Cambridge, 1979; Elaine Showalter, The Female Malady: Women, Madness and English Culture, 1830-1980, Virago 1987; Hystories: Hysterical Epidemics and Modern Media, Columbia University Press, 1997.

5. Mark Micale, Approaching Hysteria: Disease and its Interpretations, Princeton University Press, 1995; Hysterical Men: The Hidden History of Male Neurosis, Laurinda Stryker, 'Mental Cases: British Shellshock and the Politics of Interpretation', in Gail Braybon ed. Evidence, History and the Great War: Historians and the Impact of 1914-1918, Berghan, Oxford, 2003, 154-17; Tracy Loughran, 'A Crisis of Masculinity? Re-writing the History of Shellshock and Gender in First World War Britain', History Compass,11, no. 9 (2013): 727-738.

6. Jessica Meyer, Men of War: Masculinity and the First World War in Britain, Palgrave, Basingstoke, 2009. See also 'Separating the Men from the Boys: Masculinity and Maturity in Understandings of Shell Shock in Britain', Twentieth Century British History 20, no. 1 (January 1, 2009): 1-22; 'Not Septimus Now: Wives of Disabled Veterans and Cultural Memory of the First World War in Britain', Women's History Review13, no. 1 (2004): 117-138.

7. See Koureas, Memory, Masculinity and National Identity in British Visual Culture, 1914-1930: A Study of 'Unconquerable Manhood' (Ashgate, Aldershot, 2007)

8. Lois Bibbings, 'Images of Manliness: The Portrayal of Soldiers and Conscientious Objectors in the Great War', Social \& Legal Studies 12, 3, 2003, 335-358; Telling Tales About Men: Conceptions of Conscientious Objectors to Military Service During the First World War. Manchester: Manchester University Press, 2010.

9. Laura Doan, 'Sex Education and the Great War Soldier: A Queer Analysis of the Practice of 'Hetero' Sex', Journal of British Studies 51, no. 3 (July 2012): 641-663.

10. Matt Houlbrook, 'Soldier Heroes and Rent Boys: Homosex, Masculinities, and Britishness in the Brigade of Guards, circa 1900-1960', Journal of British Studies, 42, 3, July 2003, 351-388.

11. D.A. Boxwell, 'The Follies of War: Cross-dressing and Popular Theatre on the British Front Lines, 1914-18', Modernism / Modernity, 9, no. 1 (2002); Jason Crouthamel, 'Cross-dressing for the Fatherland: Sexual Humour, Masculinity and German Soldiers in the First World War', First World War Studies 2, no. 2 (October 2011): 195-215.

12. See Carden-Coyne, The Politics of Wounds: Military Patients and Medical Power in the First World War, Oxford University Press, October 2014.

13. Disabled Veterans in Britain and Germany, 1914-1939 Berkeley: University of California Press, 2001; Soldiers and the Culture of Caregiving in Britain During the Great War, Manchester : New York: Manchester University Press, 2004.

14. R.W. Connell, Masculinities, Cambridge, Polity Press; Sydney, Allen \& Unwin; Berkeley, University of California Press. Second edition, 2005; See also Wendy Gagen, "Remastering the 
Body, Renegotiating Gender: Physical Disability and Masculinity during the First World War, the Case of J.B. Middlebrook', European Review of History, 14, 4, 2007, 525-541.

15. Paul Cornish and Nicholas J. Saunders (eds), Bodies in Conflict: Corporeality, Materiality and Transformation, Routledge, Abingdon, 2014.

16. Carol Acton, 'Negotiating Injury and Masculinity in First World War Nurses' Writing', In First World War Nursing: New Perspectives, Alison S. Fell and Christine E. Hallett (eds), Routledge, London, 2013, 123-138.

17. S. Biernoff, 'Flesh Poems: Henry Tonks and the Art of Surgery', Visual Culture in Britain, 11.1 (Mar. 2010): 25-47; 'The Rhetoric of Disfigurement in First World War Britain', Social History of Medicine, February 27, 2011; S. Biernoff and J. Tynan. 'Making and Remaking the Civilian Soldier: The First World War Photographs of Horace Nicholls,' Journal of War and Culture Studies special issue: Men at War, 5.3 (Sep. 2012).

18. Smith in Bodies in Conflict: Corporeality, Materiality, and Transformation, edited by Paul Cornish and Nicholas J Saunders, 39-52. Routledge, 2014.

\section{AUTHOR}

\section{ANA CARDEN-COYNE}

Centre for the Cultural History of War, University of Manchester 